\title{
IMPROVING THE TECHNICAL POTENTIAL OF AGRARIAN ENTERPRISES
}

\author{
Mamai Oksana ${ }^{1}$, Volkonskaya Anna ${ }^{1}$, Parsova Velta ${ }^{2}$ \\ ${ }^{1}$ Samara State Agrarian University, Russia \\ ${ }^{2}$ Latvia University of Life Sciences and Technologies
}

\begin{abstract}
The technological potential of agricultural enterprise is complex system consisting of various elements with different functional capabilities and features, which are characterized by the characteristics of complex systems. The complexity of technological potential lies in the presence in structure of its several elements - technological preparation of production, equipment and technology. There is no doubt that the basis of technological potential is an active part of main production assets, namely the equipment park. Working machines and equipment, instrumentation, transmission devices and tooling - this is exactly what primarily determines the level of labour productivity. The aim of the study is to develop recommendations for efficient use of machinery of agrarian enterprises as part of their technological potential, to solve important task of developing them and improving quality and competitiveness of their products. In methodological basis of this research various methods were used: an analytical method, abstract and logical method, system approach, statistical and economic analysis, method of analogies, and method of comparative and expert estimates. The study showed that in order to increase the efficiency of use of technical equipment and more fully satisfy agricultural producers in technical services, it is necessary to create the technical centre for maintenance and repair of agricultural machines. As result, implementation of preventive strategy of technical maintenance and repair of equipment will reduce the number of machine failures by 2 - 2.5 times, increase the use of resource of their components and mechanisms by $30 \%$, and significantly reduce the loss of agricultural products due to long downtime of mechanization equipment and crop shortages while increasing agro-technical timelines for field work.

Key words: Agriculture, efficiency, potential, technology.
\end{abstract}

\section{Introduction}

Technological potential is a component of production potential of enterprise. The need to determine the category of "technological potential" at the level of main link of the economy - organization - is obvious primarily from the standpoint of increasing the efficiency of its use at all levels of production (Лысенко М., и др., 2017). Supporting the point of view of professor Kleiner, it should be noted that technological potential of particular organization consists of following components:

- technological preparation of production;

- equipment;

- technology (technological processes) (Клейнер Г.Б., 2019).

At the same time, the degree of coordination, coherence and coordination between these components is crucial for the enterprise. Inside the technological potential, own processes take place that can be divided into three groups:

- $\quad$ processes of using existing technological equipment for production (production);

- processes of creation, expansion and modernization of technological equipment of the organization (reproduction);

- $\quad$ processes that ensure creation and development of reproductive base of enterprise itself, i.e. parts of the organization providing reproduction processes.

The technological potential of agricultural organization is the complex system consisting of various elements with different functional capabilities and features, which are characterized by characteristics of complex systems.

There is no doubt that the basis of the technological potential is the active part of main production assets, namely the equipment park - working machines and equipment, instrumentation, transmission devices and technological equipment, i.e. all that primarily determines the level of labour productivity.

The effective use of the machinery of agricultural enterprises as part of their technological potential based on the implementation of scientific and technological progress is an important task of developing the organization and improving the quality and competitiveness of products. 


\section{Methodology of research and materials}

In methodological basis of this research the various methods were used: an analytical method, abstract and logical method, system approach, method of analogies, method of comparative and expert estimates, statistical and economic analysis method.

\section{Discussions and results}

At present, both at the theoretical and practical levels, unified methodology for assessing technological potential has not been developed (Melece L., Hazners J., 2017). The analysis usually starts with formation of indicators characterizing availability of agricultural machinery that has significant impact on the result of agricultural production.

Each enterprise operates and develops technologies to achieve goals and objectives in its industry. The main industry of many small agricultural enterprises in Samara region is crop production (Nipers A., et.al., 2019; Belkina E., et.al., 2019). Activities of enterprise can be assessed by main economic indicators of development (Table 1).

Table 1

The average of main technical and economic indicators of small agricultural enterprises in Samara region

\begin{tabular}{|l|c|c|c|c|c|c|}
\hline \multirow{2}{*}{\multicolumn{1}{|c|}{ Indicator }} & \multicolumn{7}{c|}{ Years } \\
\cline { 2 - 7 } & $\mathbf{2 0 1 3}$ & $\mathbf{2 0 1 4}$ & $\mathbf{2 0 1 5}$ & $\mathbf{2 0 1 6}$ & $\mathbf{2 0 1 7}$ & $\mathbf{2 0 1 8}$ \\
\hline Revenues, thous. rubles & 1401 & 449 & 855 & 1649 & 1746 & 636 \\
\hline Volume of marketable products, centners & 1340 & 977 & 979 & 1138 & 1961 & 1374 \\
\hline Net profit, thous. rubles & 151 & 89 & 75 & 165 & 170 & 150 \\
\hline Costs of main production, thous. rubles & 1220 & 548 & 890 & 1835 & 1943 & 680 \\
\hline Sales expenditures per 1 ruble, thousand rubles & 0.91 & 0.56 & 0.9 & 1.61 & 0.99 & 0.49 \\
\hline Average annual number of employees & 6 & 8 & 8 & 6 & 9 & 6 \\
\hline
\end{tabular}

Analysis showed that decrease in net profit in 2015 happened due to adverse weather conditions. In addition, as negative factor can be mentioned that state support for the agrarian sector was carried out not throughout the Samara region, but in some selected areas. For 2014 and 2015, there was a decrease in the volume of allocated funds.

To asses technical potential of enterprise it is necessary to develop the mechanism consisting of:

- $\quad$ scorecards for implementation of proposed methodologies;

- methods of generalization and systematization of source and calculated information;

- $\quad$ analysis of the results.

The need for technology has to be calculated on the basis of:

- technological maps for cultivating and harvesting crops;

- comparative economic assessment of machine and tractor units when performing different processes;

- consolidated plan of mechanized work;

- the schedule of use of machines during the calendar year.

Assessment of capacity of enterprises showed that today, on average, in the machine yard of agricultural enterprises there are different types of equipment (Table 2).

Table 2

Average number of agricultural machinery in small agricultural enterprises in Samara region

\begin{tabular}{|l|c|c|c|c|c|c|}
\hline \multicolumn{1}{|c|}{ Equipment } & \multicolumn{5}{c|}{ Years } \\
\cline { 2 - 7 } & $\mathbf{2 0 1 3}$ & $\mathbf{2 0 1 4}$ & $\mathbf{2 0 1 5}$ & $\mathbf{2 0 1 6}$ & $\mathbf{2 0 1 7}$ & $\mathbf{2 0 1 8}$ \\
\hline $\begin{array}{l}\text { Tractors of all brands (without tractors on which the } \\
\text { machines are mounted) }\end{array}$ & 3 & 3 & 4 & 7 & 10 & 12 \\
\hline Tractors on which the machines are mounted & 1 & 1 & 1 & 1 & 1 & 1 \\
\hline Tractor trailers & - & - & - & 2 & 2 & 2 \\
\hline Seeding machines & - & 2 & 2 & 2 & 3 & 3 \\
\hline Harvesters & 1 & 1 & 1 & 1 & 2 & 2 \\
\hline Trucks & 3 & 3 & 3 & 3 & 3 & 3 \\
\hline
\end{tabular}


The presence of technology implies its intended use in the fields however an important criterion is the sufficiency of this equipment to satisfy all needs, ensuring the full load of equipment (Parsova V., et.al., 2018; Yanzina E. et.al., 2019) (Table 3).

Table 3

Average provision of enterprises with certain types of equipment

\begin{tabular}{|c|c|c|c|c|c|c|c|c|}
\hline \multirow[b]{2}{*}{ Types of equipment } & \multirow{2}{*}{$\begin{array}{l}\text { Nor } \\
\text { ma- } \\
\text { tive }\end{array}$} & \multicolumn{6}{|c|}{ Years } & \multirow{2}{*}{$\begin{array}{l}\text { Change } \\
\text { 2018/ } \\
\text { 2013, \% }\end{array}$} \\
\hline & & 2013 & 2014 & 2015 & 2016 & 2017 & 2018 & \\
\hline \multirow{2}{*}{$\begin{array}{l}\text { Total number of tractors including } \\
\text { per } 100 \text { hectares of arable land, pcs. }\end{array}$} & - & 10 & 10 & 10 & 11 & 12 & 12 & 120 \\
\hline & 1.0 & 0.51 & 0.51 & 0.51 & 0.59 & 0.64 & 0.64 & 110 \\
\hline \multirow{2}{*}{$\begin{array}{l}\text { Total number of combine harvesters } \\
\text { including per } 1000 \text { ha of grain } \\
\text { crops, pcs. }\end{array}$} & - & 2 & 2 & 2 & 2 & 2 & 2 & 100 \\
\hline & 3.5 & 2.8 & 2.8 & 2.6 & 2.7 & 2.7 & 2.8 & 100 \\
\hline Total number of trucks, pcs. & - & 3 & 3 & 3 & 3 & 3 & 3 & 100 \\
\hline
\end{tabular}

Analysis of availability of equipment showed an increase in certain types of categories. So the number of tractors increased by 2 units or $20 \%$, which allowed reduce the load on one tractor due to constant area of arable land. Growth in the number of combine harvesters reflects the positive dynamics of the development of enterprises.

It should be noted that equipment park is being updated. High level of mechanization is observed in the cultivation of grain $(90 \%)$. In addition, small agricultural enterprises have workshops that allow perform quick machine repair and maintenance. For determination of production capacity, the methodology, determining of balanced indicator of production capacity of enterprises have been used in the cost estimate in course of the study. To assess the technical potential of enterprises, it is advisable to use indicators and their dynamics, showed in Table 4.

Table 4

Average indicators of fixed assets of small agricultural enterprises in Samara region

\begin{tabular}{|l|c|c|c|c|c|c|}
\hline \multirow{2}{*}{ Indicator } & \multicolumn{7}{c|}{ Years } \\
\cline { 2 - 7 } & $\mathbf{2 0 1 3}$ & $\mathbf{2 0 1 4}$ & $\mathbf{2 0 1 5}$ & $\mathbf{2 0 1 6}$ & $\mathbf{2 0 1 7}$ & $\mathbf{2 0 1 8}$ \\
\hline Profit, thous. rubles & 151 & 89 & 75 & 165 & 170 & 150 \\
\hline Fixed assets, thous. rubles & 8139 & 8014 & 7768 & 6592 & 6742 & 7100 \\
\hline $\begin{array}{l}\text { Average annual value of fixed assets, thous. } \\
\text { rubles }\end{array}$ & 8149 & 7864 & 5398 & 7944 & 8002 & 6117 \\
\hline $\begin{array}{l}\text { Cost of active part of fixed assets, thous. } \\
\text { rubles: }\end{array}$ & & & & & \\
\hline - at beginning of the year & 5040 & 5104 & 6124 & 6162 & 6618 & 6742 \\
\hline - at end of the year & 5104 & 6124 & 6262 & 6618 & 6742 & 7082 \\
\hline Newly introduced funds, thous. rubles & - & - & - & - & - & - \\
\hline Retired fixed assets, thous. rubles & 110 & 58 & 67 & 70 & 83 & - \\
\hline Amount of depreciation, thous. rubles & 3032 & 6685 & 6790 & 5044 & 6980 & 7050 \\
\hline Power capacity, hp & 270 & 270 & 270 & 270 & 270 & 270 \\
\hline Number of employees & 6 & 8 & 8 & 6 & 9 & 6 \\
\hline Area of agricultural land, ha & 479 & 479 & 479 & 479 & 479 & 479 \\
\hline
\end{tabular}

Analysis of fixed assets shows the dynamics of changes in indicators over past 6 years of operation of enterprises. So, the area of 479 hectares remained unchanged, slight decrease occurred in the structure of employees (by 25\% since 2016). For other indicators can be noted both positive (upward) and negative (downward) dynamics. Fixed assets increased by 105\% (7100 thousand rubles) compared with 2017, and growth of energy capacities remained unchanged.

\section{Conclusions and proposals}

In order to increase the efficiency of using technical equipment and more fully satisfy agricultural producers in production and technical services, it is necessary to create a technical centre for servicing and repairing agricultural machines. The repair or maintenance centre of the agro-industrial complex is 
small organization, which is the team of employees armed with means of production and performing maintenance work, restoring the resource or working capacity of machinery and equipment.

The main task of such centre is the timely and high-quality performance of work in the field of technical service and repair of agricultural machinery, the restoration of components and parts of it, provision of repair production of technological equipment, improvement of technological processes and implementation of repair work at all levels of the repair network.

Main functions of the repair centre have to be:

- $\quad$ certification of equipment;

- development of technological processes of repair;

- organization and planning of maintenance and repair of equipment;

- maintenance, repair and upgrade of equipment;

- improvement of qualification of repair personnel.

Economic efficiency will be achieved by saving financial resources, making repair of agricultural machines and other equipment instead of purchase of new ones. The effectiveness of technical service is determined by the initial technical and economic characteristics of machines, their level of use, timeliness of maintenance and repair.

As result, implementation of preventive strategy of technical maintenance and repair of equipment will reduce the number of machine failures by $2-2.5$ times, increase use of resource of their components and mechanisms by $30 \%$, and significantly reduce loss of agricultural products due to long downtime of mechanization equipment and crop shortages while increasing agro-technical timelines for field work.

\section{References}

1. Belkina E., Zaytseva M., Galenko N., Volkonskaya A., Kurlykov O. (2019) Ecovillage as an instrument to attract the working population to the countryside. Indo American journal of pharmaceutical sciences, vol. 3, pp. 6243-6248.

2. Melece L., Hazners J. (2017) Factors influencing Latvian small and medium enterprises towards ecoinnovation. Proceedings of 16th international scientific conference "Engineering for rural development", Jelgava, pp. 1466-1473

3. Nipers A., Pilvere I., Krievina A., Bratka V. (2019) Projecting investments and fixed assets in agriculture in Latvia. Proceedings of 18th international scientific conference "Engineering for rural development", Jelgava, pp. $1779-1785$

4. Parsova V., Mamai O., Zudilin S. (2018) Assessment of efficiency of use of agricultural land: example of Samara region. Proceedings of $17^{\text {th }}$ International Scientific Conference "Engineering for Rural Developmentt", Jelgava, pp. 624-631

5. Yanzina E. Yanzin V., Mamai O., Parsova V. (2019) Improving efficiency of agricultural machinery exploitation as factor of optimization use of agricultural land. Proceedings of 18th international scientific conference "Engineering for rural development", Jelgava, pp. 117-122

6. Клейнер Г.Б. (2019) Экосистема предприятия: внутренне наполнение и внешнее окружение (Enterprise ecosystem: internal content and external). Strategic Planning and Enterprise Development: Plenary Reports of the Nineteenth All-Russian Symposium, Moscow, pp. 6-13. (In Russian)

7. Лысенко М., Лысенко Ю., Мингалев В., Шарапова В. (2017) Технический потенциал сельскохозяйственных организаций и его оптимизация (Technical potential of agricultural organizations and its optimization). Agrarian Bulletin of the Urals, vol. 12 (166), pp. 91-99. (In Russian)

Information about authors:

Mamai Oksana, Doctor of economic sciences, professor, Department of Management and Marketing of Samara State Agrarian University. Address: 446442 Russian Federation, Samara region, settlement Ust'-Kinelsky, Uchebnaja 2, phone: +7 9272626873, e-mail: mamai_ov@ssaa.ru. Fields of interest: management consulting, innovative development of the agricultural sector, digitalization of agriculture

Volkonskaya Anna, $\mathrm{PhD}$ in Economics, Head of the Department of Management and Marketing of Samara State Agrarian University. Address: 446442 Russian Federation, Samara region, settlement Ust'-Kinelsky, Uchebnaja 2, phone: +7 9649823259, e-mail: gold.eka@yandex.ru Fields of interest: personnel management, digital economy, digital politics

Parsova Velta, Dr.oec., professor, Department of Land Management and Geodesy of Latvia University of Life Sciences and Technologies. Address: 19, Akademijas str., Jelgava, LV-3001, phone: +371 29118285, e-mail: velta@parsova.lv Fields of interest: cadastre, real property formation, land management 